\title{
Contemporary Pharmacotherapeutics and the Management of Aggressive Behavior in an Adolescent Animal Model of Maladaptive Aggression
}

\author{
Clare Einberger ${ }^{1}$, Amanda Puckett ${ }^{1}$, Lesley Ricci ${ }^{1}$, Richard Melloni Jr. ${ }^{1,2}$ \\ ${ }^{1}$ Department of Psychology, ${ }^{2}$ Program in Behavioral Neuroscience, Northeastern University, Boston, MA, USA
}

\begin{abstract}
Objective: Antipsychotic and anticonvulsant medications are increasingly being used as pharmacotherapeutic treatments for maladaptive aggression in youth, yet no information is available regarding whether these drugs exhibit aggressionspecific suppression in preclinical studies employing adolescent animal models of maladaptive aggression. This study examined whether the commonly used antipsychotics medications haloperidol and risperidone and the anticonvulsant medication valproate exert selective aggression-suppressing effects using a validated adolescent animal model of maladaptive aggression.

Methods: Twenty-seven-day old Syrian hamsters (Mesocricetus auratus) were administered testosterone for 30 consecutive days during the first 4 weeks of adolescent development. The following day (during late adolescence), experimental animals received a single dose of haloperidol $(0.00,0.025,0.50,1.0 \mathrm{mg} / \mathrm{kg})$, risperidone $(0.00,0.01,0.03,1.0 \mathrm{mg} / \mathrm{kg})$, or valproate $(0.00,1.0,5.0,10.0 \mathrm{mg} / \mathrm{kg})$ and tested for offensive aggression using the Resident/Intruder Paradigm. As a baseline, non-aggressive behavioral control, a separate set of pubertal hamsters was treated with sesame oil vehicle during the first 4 weeks of adolescence and then tested for aggression during late adolescence in parallel with the haloperidol, risperidone or valproate-treated experimental animals.

Results: Risperidone and valproate selectively reduced the highly impulsive and intense maladaptive aggressive phenotype in a dose-dependent fashion. While haloperidol marginally reduced aggressive responding, its effects were non-specific as the decrease in aggression was concurrent with reductions in a several ancillary (non-aggressive) behaviors. Conclusion: These studies provide pre-clinical evidence that the contemporary pharmacotherapeutics risperidone and valproate exert specific aggression-suppressing effects in an adolescent animal model of maladaptive aggression.
\end{abstract}

KEY WORDS: Adolescent; Aggression; Antipsychotic agents; Anticonvulsants; Pharmacotherapy.

\section{INTRODUCTION}

While aggressive behaviors in children and adolescents are normal and serve an important evolutionary purpose [1], aggression in psychiatrically referred youth is often considered maladaptive and is believed to represent a disordered internal mechanism [1]. Maladaptive aggression in the absence of other symptoms, labeled Intermittent Explosive Disorder, is an impulsive, highly reactive and intense form of aggressive behavior with a lifetime preva-

Received: August 7, 2019/ Revised: September 20, 2019

Accepted: September 21, 2019

Address for correspondence: Richard Melloni Jr.

Department of Psychology, Northeastern University, 360

Huntington Ave., Boston, MA 02115, USA

E-mail: r.melloni@northeastern.edu

ORCID: https://orcid.org/0000-0002-2203-3685 lence of $5.4-7.3 \%$ [2] and symptoms during adolescence can lead to negative outcomes such as social isolation, discontentment [3]. Maladaptive aggression itself is not a disorder [4], rather it is considered an attribute of a variety of psychiatric conditions such as autism [5], post-traumatic stress disorder [6], schizophrenia [7], attention deficit/hyper activity disorder (ADHD) [8], antisocial personality disorder and borderline personality disorder [4], and bipolar disorder [9]. In youth with comorbid ADHD, maladaptive aggression is a predictor of physical aggression, criminality and decreased quality of life during adolescence and adulthood [10]. Given the prevalence and negative outcomes of maladaptive aggression in youth, effective treatments that selectively target the aggressive behavioral response are needed.

(ㄷ) This is an Open-Access article distributed under the terms of the Creative Commons Attribution Non-Commercial License (http://creativecommons.org/licenses/by-nc/4.0) which permits unrestricted non-commercial use, distribution, and reproduction in any medium, provided the original work is properly cited. 
Antipsychotic medications and anticonvulsant mood stabilizers are used as pharmacotherapeutic treatments for maladaptive aggression in a variety of adolescent psychiatric settings [11-16]. The administration of these medications to youth has increased since the 1990's $[17,18]$, with younger patients representing the largest pediatric diagnostic group to receive such medications for the treatment of highly aggressive and disruptive behavioral disorders [19]. While there is an increased frequency of prescriptions of these medications in younger populations, there is little evidence beyond small cohort observations [20], to suggest that the typical class of antipsychotics such as haloperidol (or thioridazine) reduce maladaptive aggression in youth with other psychiatric diagnoses [21]. In fact, the 2015 Canadian guidelines recommended against the use of haloperidol as treatment for aggressive youth with ADHD, oppositional defiant disorder, or conduct disorder due to insubstantial evidence and significant side effects [22]. Yet, according to a recent meta-analysis in adults with maladaptive aggression, independent of concurrent psychiatric diagnosis, haloperidol and other first generation antipsychotics show relative benefits similar to that of other therapeutic interventions [23]. Haloperidol produces significant side effects, including weight gain, photosensitivity, arrhythmia, seizures, extrapyramidal symptoms, sedation, and cognitive impairment as well as permanent diagnoses such as tardive dyskinesia [24]. These side effects complicate research efforts to assess the aggression suppressing effects of haloperidol. To this effect, there is limited research on whether haloperidol could serve as an effective treatment for maladaptive aggression in youth, and its use is declining, since the rising use of the atypical class of antipsychotic medications. A New Zealand longitudinal study, found that $47 \%$ of all atypical antipsychotics prescribed for youth listed maladaptive aggression as the main target symptom [25]. In youth with conduct disorder or autism, the atypical antipsychotic risperidone was effective for the treatment of severely disruptive behaviors and maladaptive aggression [26-29]. Interestingly, in patients who fail to respond to antipsychotic medications like risperidone, the use of the anticonvulsant mood stabilizer valproate to treat aggression in clinical settings has produced consistently reliable results [30]. Moreover, valproate has been shown effective for the treatment of disruptive behaviors and maladaptive aggression in youth with behav- ioral problems [16,30-32].

To assess the aggression-specific efficacy of haloperidol, risperidone and valproate, to treat maladaptive aggression in youth, we investigated the effectiveness of these medications in an established adolescent animal model of maladaptive aggression. Clinical research has been successful in identifying and validating proactive and reactive subtypes of aggression in adolescent populations $[1,33]$. Proactive aggression is controlled, planned and driven by reward contingencies while reactive aggression is characterized as an over-aroused, impulsive and intense aggressive response to a perceived threat [1] Reactive aggression is the most common form of aggressive behavior observed in psychiatrically referred youth and is categorized as a maladaptive aggression [1] In terms of construct validity, escalated offensive aggression in animals possesses many of the same behavioral characteristics as reactive aggression in humans [34-36]. Like reactive aggression, escalated offensive aggression is described as a highly aroused, impulsive and intense form of aggressive behavior directed towards a perceived threat, in this case a conspecific animal. Discriminating between aggression subtypes is important as the brain mechanisms modulating different subtypes of aggression are distinct in both animals [37] and humans [38], and appropriate responses to pharmacological interventions may differ across aggression subtype. For the most part, preclinical studies that have examined drug effects on aggression have not used methodologies that were sensitive to these distinctions. In reports where antipsychotic medications were found to reduce aggression in adult animal models, significant results were only produced when the drugs were administered at high doses or in combination with agents sharing similar neurochemical properties $[39,40]$; although in at least one study using genetically modified animals, risperidone was found to reduce aggression at low doses, i.e., $0.03-0.1 \mathrm{mg} / \mathrm{kg}$ [41]. Similarly, we showed that low doses of risperidone reduced aggression in pubertal animals stimulated to respond hyper aggressively by chronic exposure to psychostimulants $[42,43]$. Our studies were the first preclinical studies to provide evidence that risperidone possessed anti-aggressive effects in adolescent animals. Presently, no information is available regarding the comparative efficacy of haloperidol, risperidone and/or valproate, in selectively suppressing aggressive behavior us- 
ing validated adolescent animal models of maladaptive aggression.

Over the past two decades, we have established and validated a pharmacologic model of maladaptive aggression in adolescent Syrian hamsters [44-47]. This model is particularly useful for the study of maladaptive aggression as these pubertal animals display a highly reactive form of aggressive responding that is characterized by an impulsive, intense, and targeted aggressive response pattern. Indeed, rapid, prolonged, and highly intense offensive acts define the highly reactive aggressive phenotype in animals [48]. In our model, animals exhibit short attack and bite latencies (an indicator of high aggressive impulsivity) in addition to frequent and prolonged bouts of offensive attacks (a indicatory of high aggression intensity) [46]. Additionally, pubertal hamsters in this model display targeted and developmentally mature aggressive responses independent of social context and in the absence of necessary social cues. In fact, aggression in these animals exceeds that of adult "trained fighters" (i.e., hamsters trained to respond aggressively) hat are stimulated to respond hyper-aggressively by the direct activation of neural circuits stimulating aggression [49].

Although there is evidence that antipsychotics and anticonvulsants reduce maladaptive aggression in children and adolescents [13], recent studies have called for more extensive preclinical investigation to address whether these medications specifically lessen maladaptive aggression in youth, and how aggressive behaviors are modulated by these substances [21]. Existing data is often complicated by factors such as polypharmacy, concurrent treatments, variations in psychiatric presentation and diagnoses, as well as social dynamics [50]. From a preclinical perspective, our adolescent animal model of maladaptive aggression can inform clinical practice by isolating reactive aggressive phenotypes from confounding variables that complicate human research. The studies presented here examine whether acute administration of therapeutically relevant doses of typical and atypical antipsychotics and anticonvulsant mood stabilizers are effective at reducing the highly reactive aggressive phenotype observed in our validated adolescent animal model of maladaptive aggression.

\section{METHODS}

\section{Experimental Animals}

The pubertal or "adolescent" period of development in Syrian hamsters can be approximated as the time between Postnatal Day 25 and 65 (PD25-65). Weaning generally occurs around PD25, with the onset of puberty (as determined by the onset of gonadal maturation) around PD30 [51]. Testosterone levels start to rise at around PD30, reaching near peak levels by $\mathrm{P} 45$ and finally peaking between PD60 and PD65 [51]. During this developmental time period, hamsters wean from their dams, leave the home nest, establish new, solitary nest sites, and learn to defend their territory and participate in social-dominance hierarchies $[51,52]$.

For the experimental treatment paradigm, intact pubertal male hamsters (PD21) were obtained from Charles River Labs (Wilmington, MA, USA), individually housed in polycarbonate cages, and maintained at ambient room temperature on a reverse light-dark cycle (14 hours light:10 hours dark; lights on at 6:00 PM). Food and water were provided ad libitum. For aggression testing, stimulus (intruder) males of equal size and weight to experimental animals were obtained from Charles River one week before behavioral tests, group-housed at 5 animals/cage in large polycarbonate cages, and maintained as described to acclimate to the animal facility. All intruders were prescreened for a low level of social interest (i.e., disengage and evade) and environmental fear responses (i.e., tail-up freeze, flee, and fly-away) one day before the aggression test to control for behavioral differences between stimulus animals as described $[45,53,54]$. Intruders displaying significantly low aggression or submissive postures $(<5 \%)$ were excluded from use in behavioral tests. All procedures in the following sections comply with the National Institutes of Health guide for the care and use of Laboratory animals (NIH Publications No. 8023, revised 1978) and were preapproved by the Northeastern University Institutional Animal Care and Use Committee (NU-IACUC).

\section{Treatment and Groups}

Pubertal (PD27) Syrian hamsters $(n=150)$ received daily subcutaneous (SC) injections $(0.1-0.2 \mathrm{ml})$ of a mixture of testosterone and its synthetic analogs consisting of 2 $\mathrm{mg} / \mathrm{kg}$ testosterone cypionate, $2 \mathrm{mg} / \mathrm{kg}$ nandrolone decanoate, and $1 \mathrm{mg} / \mathrm{kg}$ boldenone undecylenate dissolved 
in sesame oil, for 30 consecutive days during the first 4 weeks of adolescent development (PD27-PD56). This treatment regimen has been shown repeatedly to produce highly aggressive adolescent animals in greater than 90\% of the treatment pool [46]. The day after the last injection (PD57; during late adolescence), experimental animals were randomly assigned to one of 10 treatment groups ( $\mathrm{n}=$ $12-15$ animals per group) and were tested for offensive aggression following a single intraperitoneal injection of saline $(0.9 \% \mathrm{mg} / \mathrm{kg} / \mathrm{ml})$, haloperidol $(0.025,0.50,1.0$ $\mathrm{mg} / \mathrm{kg})$, risperidone $(0.01,0.03,1.0 \mathrm{mg} / \mathrm{kg})$, or valproate $(1.0,5.0,10.0 \mathrm{mg} / \mathrm{kg})$. All injections were performed on unanesthetized animals and took no longer than 10 seconds. After injection, animals were returned to their home cage. Then 30 minutes later, animals were tested for offensive aggression. Doses of all pharmaceutical agents were selected on the basis of previous reports indicating dose-response efficacy in humans and animals and allometrically scaled using calculations and pharmacokinetic parameters as described $[55,56]$. As a baseline, non-aggressive behavioral control, a separate set of pubertal hamsters $(n=15)$ was treated with sesame oil vehicle instead of testosterone during the first 4 weeks of adolescence (PD27 - PD56) and then tested for aggression on P57 (during late adolescence) in parallel with the haloperidol, risperidone or valproate-treated experimental animals.

\section{Aggressive Behavior}

Adolescent animals were tested for offensive aggression using the resident-intruder paradigm, a well-characterized and ethologically valid model of offensive aggression $[57,58]$. Briefly, an intruder of similar size and weight was introduced into the home cage of the experimental animal (resident), and the resident was scored for (1) general measures of aggression intensity (i.e., number of attacks and bites) and aggressive impulsivity (i.e., latency to attack and bite) toward intruders as we described elsewhere [45] and (2) more specific and targeted aggressive responses, including upright offensive attacks, lateral attacks, head/nape bites, and flank/rear bites as we described [59], to provide a more detailed account of the aggressive encounter between experimental residents and intruders. An attack was scored each time that the resident animal would pursue and then either (1) lunge toward or (2) confine the intruder by upright and sideways threat, each generally followed by a direct attempt to bite the in- truder's dorsal rump or flank target areas. Composite aggression scores, used as a broad measure of offensive aggression, were defined as the total number of attacks (i.e., upright offensive and lateral attacks) and bites (i.e., head/nape and flank/rear bites) during the behavioral test period. The latency to attack and bite was defined as the period of time between the beginning of the behavioral test and the first attack and bite of the residents toward an intruder. In the case of no attacks or bites, latencies were assigned the maximum time of the test duration (i.e., 600 seconds). Each aggression test lasted for 10 minutes and was videotaped and coded manually by two observers who were unaware of the hamsters' experimental treatment. Differences in scores for all behaviors measured were less than $5 \%$ between the two observers. No intruder was used for more than one behavioral test, and all animals were tested during the first 4 hours of the dark cycle under dim-red illumination to control for circadian influences on behavior.

\section{Ancillary Behavior}

In addition to aggression, adolescent animals were tested for an array of social, comfort, and motor behaviors during the 10 minutes encounter to control for nonspecific effects of haloperidol, risperidone and valproate on general measures of behavioral activation. Specifically, animals were measured for social communication (i.e., flank marking), locomotion (i.e., line crosses), comfort (i.e., grooming), and avoidance/escape (i.e., wall climbing).

\section{Statistics}

Results from the aggression tests were compared across treatment conditions. The calculations was made in the Social Science Statistics Software (www.socscistatistics. com). Aggressive and ancillary behaviors were compared by using one-way ANOVA followed by post-hoc pair-wise planned comparison $t$ tests (two-tailed). The $\alpha$ level for all experiments was set at $p=0.05$.

\section{RESULTS}

As we reported [46], hamsters administered testosterone during adolescence display a highly escalated and reactive form of aggression that is characterized by rapid (i.e., impulsive), sustained (i.e., intense), and targeted (i.e., mature) aggressive responding (Fig. 1). Experimental (tes- 
tosterone-treated) animals were significantly more aggressive than vehicle-treated controls as measured by composite scores of aggression ( $\mathrm{t}(17)=7.16, p<0.001$ ); directing greater than tenfold more offensive attacks and bites onto conspecifics than control animals. When examined more closely, experimental animals targeted significantly more lateral attacks (t $(17)=6.77, p<0.001$ ) and bites targeting the flank/rear region of conspecifics ( $t$ $(14)=6.26, p<0.001)$. In fact, experimental animals ex- hibited a greater than tenfold increase in the number of lateral attacks and nearly twentyfold increase in the number of bites targeted towards the flank/rear. In addition, experimental animals were substantially faster to attack $(\mathrm{t}$ $(17)=6.06, p<0.001)$ and bite $(\mathrm{t}(17)=7.07, p<0.001)$ conspecifics than vehicle-treated control animals. Overall, experimental animals were six times faster to attack and four times quicker to bite intruders compared to littermate controls.
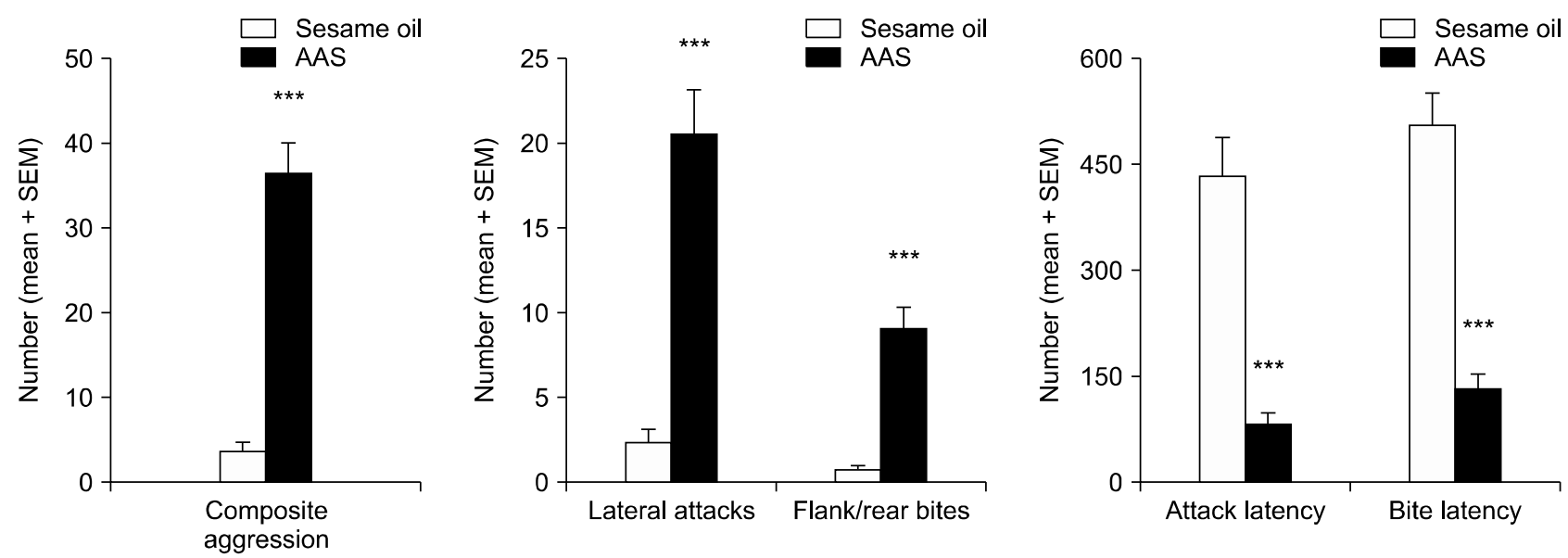

Fig. 1. Maladaptive aggression in an adolescent animal model. Pubertal hamsters administered testosterone display a highly reactive form of aggression that is characterized by a rapid (i.e., impulsive), sustained (i.e., intense), and targeted (i.e., mature) aggressive response as indicated by increased composite aggression scores, lateral attacks, and flank/rump bites and decreased latency to attack and bite compared to non-aggressive vehicle control animals.

AAS, anabolic - androgenic steroids; SEM, standard error of the mean. *** $p<0.001$.
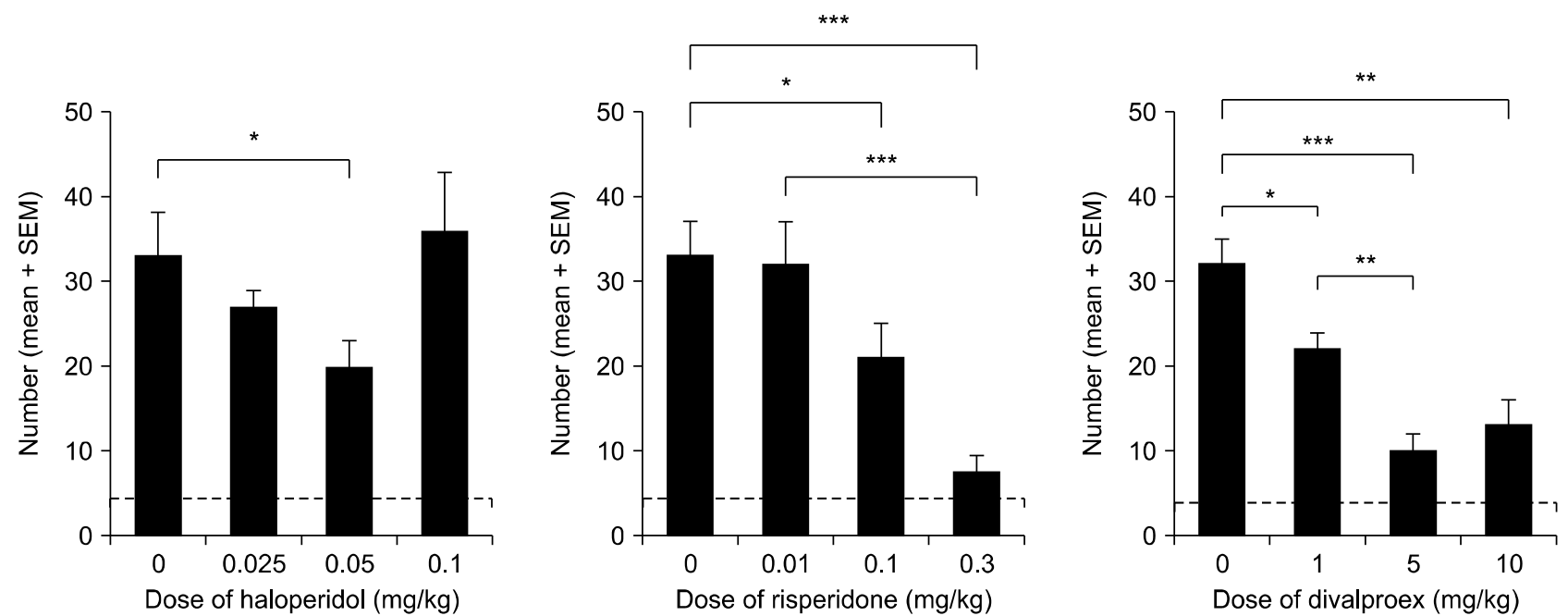

Fig. 2. Effects of haloperidol, risperidone, and valproate on composite aggression scores (i.e., a broad measure of aggression intensity). Haloperidol marginally reduced composite aggression at a single dose $(0.05 \mathrm{mg} / \mathrm{kg})$, while risperidone $(0.1-0.3 \mathrm{mg} / \mathrm{kg})$ and valproate $(1-5 \mathrm{mg} / \mathrm{kg})$ dose dependently decreased composite aggression across several drug doses in aggressive experimental animals. The dashed line represents the baseline behavioral response of non-aggressive, control animals. Bars denote standard error of the mean. ${ }^{*} p<0.05,{ }^{* *} p<0.01,{ }^{* * *} p<0.001$. 


\section{Antipsychotics and Maladaptive Aggression}

\section{Haloperidol}

The systemic administration of the typical antipsychotic haloperidol to aggressive, experimental animals produced an overall effect on aggression intensity as measured by composite scores of aggression $\left(\mathrm{F}_{(3,28)}=3.91, p<0.05\right)$ with anti-aggressive effects seen at a moderate $(0.05$ $\mathrm{mg} / \mathrm{kg}$ ) dose of haloperidol. At this dose haloperidol significantly reduced composite aggression toward intruders when compared to saline-treated controls $(\mathrm{t}(15)=2.47, p<$ 0.05) (Fig. 2). When examined more precisely, haloperidol produced an overall effect on the bites targeted towards the flank/rear region of intruders $\left(\mathrm{F}_{(3,26)}=3.53, p<\right.$ 0.05). At $0.025 \mathrm{mg} / \mathrm{kg}$ haloperidol marginally decreased the number of bites onto the flank/rear region of intruders (t $(14)=2.08, p=0.06$ ), while at $0.05 \mathrm{mg} / \mathrm{kg}$ haloperidol the decrease in the number of bites delivered onto the flank/rear of intruders was statistically significant $(\mathrm{t}(14)=$ $2.57, p<0.05)$ compared to saline $(0.0 \mathrm{mg} / \mathrm{kg})$ controls (Fig. 3). No similar effects were seen at higher doses of haloperidol (i.e., $0.1 \mathrm{mg} / \mathrm{kg} ; \mathrm{t}(14)=1.7, p=0.1$ ). Haloperidol also produced a marginal overall effect on aggressive impulsivity as measured by latency to bite $\left(\mathrm{F}_{(3,24)}=2.54, p=\right.$ 0.08 ), however this effect was only significant (and just so) at $0.05 \mathrm{mg} / \mathrm{kg}$ compared to saline $(0.0 \mathrm{mg} / \mathrm{kg}$ ) controls (t $(14)=2.19, p=0.049$ ) (Fig. 3). No significant effects of haloperidol were observed at any dose on lateral attack behavior $\left(\mathrm{F}_{(3,24)}=1.99\right)$ or on the latency to attack $\left(\mathrm{F}_{(3,24)}=\right.$ 0.36) ( $p>0.05$ each comparison).

The systemic administration of haloperidol to aggressive, experimental animals also produced an overall
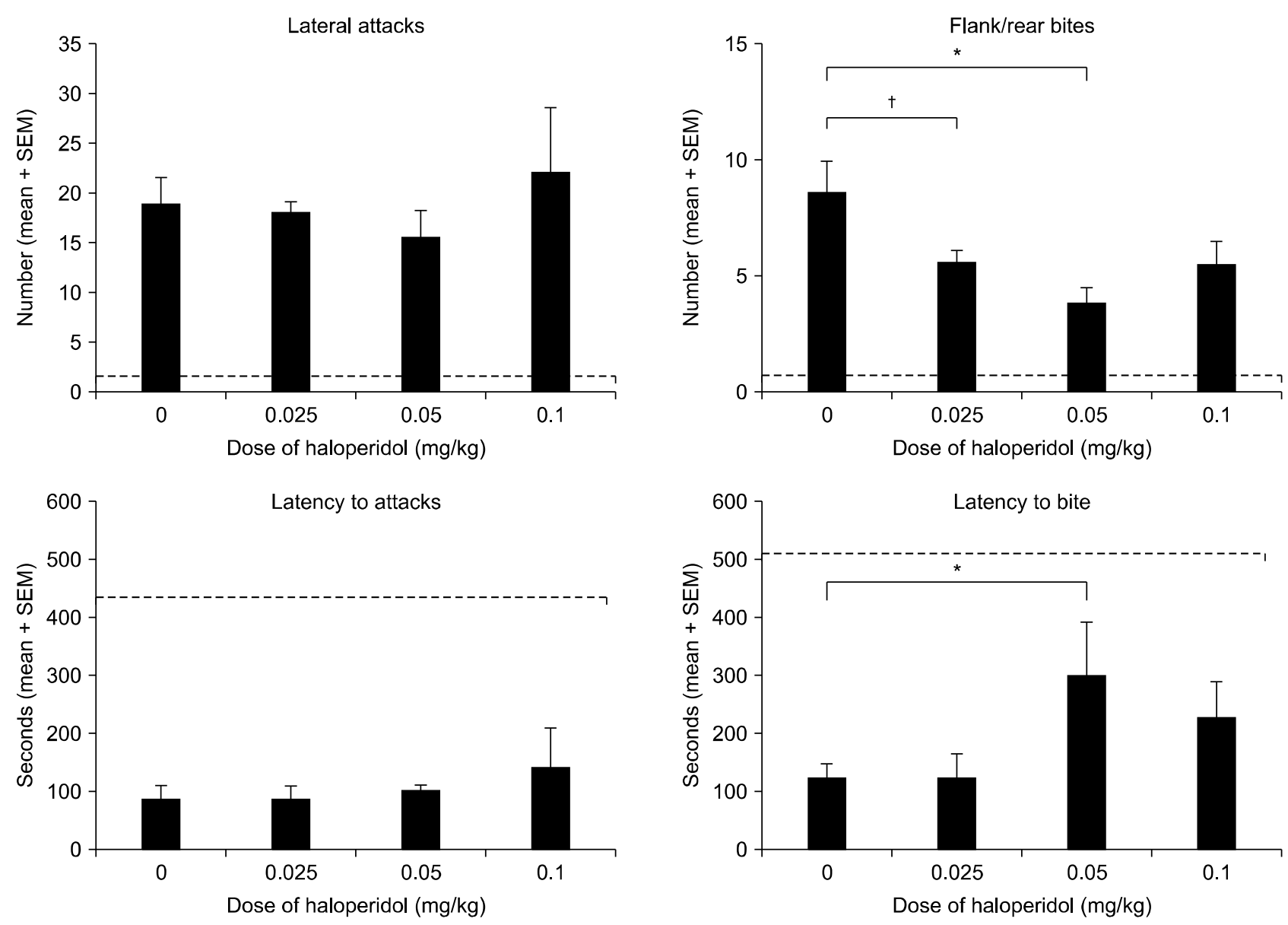

Fig. 3. Effects of haloperidol on aggression. Haloperidol treatment reduced few measures of aggression intensity (i.e., number of flank/rear bites) and initiation (i.e., mean latency to first bite), and only at a single dose ( $0.05 \mathrm{mg} / \mathrm{kg}$, intraperitoneal) compared to saline-treated counterparts. Dashed lines in represent the baseline behavioral response of non-aggressive, control animals. Bars denote standard error of the mean.

${ }^{\dagger} 0.05<p<0.1, * p<0.05$. 
Table 1. Effects of haloperidol on ancillary behavior

\begin{tabular}{|c|c|c|c|c|c|}
\hline \multirow{2}{*}{ Behavior } & \multicolumn{5}{|c|}{ Dose } \\
\hline & $0.0 \mathrm{mg} / \mathrm{kg}$ & $0.025 \mathrm{mg} / \mathrm{kg}$ & $0.05 \mathrm{mg} / \mathrm{kg}$ & $0.1 \mathrm{mg} / \mathrm{kg}$ & $p$ value \\
\hline Social behavior & & & & & \\
\hline $\begin{array}{l}\text { Flank marks } \\
\text { Locomotion }\end{array}$ & $2.1 \pm 0.49$ & $3.01 \pm 1.2$ & $2.0 \pm 0.63$ & $1.75 \pm 0.55$ & 0.72 \\
\hline $\begin{array}{l}\text { Line crosses } \\
\text { Comfort behavior }\end{array}$ & $33.13 \pm 2.82$ & $26.13 \pm 3.58^{\wedge}$ & $22.65 \pm 2.46^{*}$ & $29 \pm 5.45$ & 0.031 \\
\hline $\begin{array}{l}\text { Grooming } \\
\text { Avoidance/escape }\end{array}$ & $3.87 \pm 0.71$ & $2.65 \pm 0.72$ & $2.25 \pm 0.6^{\wedge}$ & $1.25 \pm 0.48^{* *}$ & 0.034 \\
\hline Wall climbs & $7.95 \pm 1.57$ & $8.67 \pm 1.75$ & $9.5 \pm 1.65$ & $9.63 \pm 2.6$ & 0.2 \\
\hline
\end{tabular}

Values are presented as mean \pm standard deviation. Haloperidol has marginal-to-significant effects on social, motor, comfort, and avoidance behaviors.

Compared to $0.0 \mathrm{mg} ;{ }^{\wedge} 0.05<p<0.1,{ }^{*} p<0.05,{ }^{* *} p<0.01$.

effect on several key measures of ancillary behaviors, including motor (i.e., line crosses; $\mathrm{F}_{(3,28)}=3.34$ ) and comfort (i.e., grooming; $\left.F_{(3,28)}=3.30\right)$ behaviors $(p<0.05$ each comparison) (Table 1). Specifically, a trend towards a decrease in the number of line crosses was observed at $0.025 \mathrm{mg} / \mathrm{kg}$ haloperidol ( $\mathrm{t}(14)=1.85, p=0.08$ ) as compared to saline $(0.0 \mathrm{mg} / \mathrm{kg})$ controls, while $0.05 \mathrm{mg} / \mathrm{kg}$ haloperidol significantly reduced the number of line crosses $(\mathrm{t}(14)=2.78, p<0.05)$ compared to saline $(0.0 \mathrm{mg} / \mathrm{kg})$ controls. Similarly, a trend towards a decrease in grooming behavior was observed at $0.05 \mathrm{mg} / \mathrm{kg}$ haloperidol $(\mathrm{t}$ $(14)=1.87, p=0.08)$ as compared to saline $(0.0 \mathrm{mg} / \mathrm{kg})$ controls, while $0.1 \mathrm{mg} / \mathrm{kg}$ haloperidol significantly reduced grooming (t $(14)=3.26, p<0.05$ ) compared to saline $(0.0 \mathrm{mg} / \mathrm{kg})$ controls. However, no significant effects were observed on measures of social communication (i.e., flank marking; $F_{(3,24)}=0.72$ ) or avoidance/escape (wall climbs; $\left.F_{(3,24)}=0.20\right)$ behaviors, $(p>0.05$ each comparison).

\section{Risperidone}

The systemic administration of the atypical antipsychotic risperidone to aggressive, experimental animals also produced an overall effect on aggression intensity as measured by composite scores of offensive aggression $\left(\mathrm{F}_{(3,35)}=11.03, p<0.001\right)$ with anti-aggressive effects beginning at the $0.1 \mathrm{mg} / \mathrm{kg}$ dose and continuing to the 0.3 $\mathrm{mg} / \mathrm{kg}$ dose. At these doses, risperidone treatment significantly reduced composite aggression towards intruders when compared with saline-treated control $(0.0$ $\mathrm{mg} / \mathrm{kg})$ animals $(0.1 \mathrm{mg} / \mathrm{kg}, \mathrm{t}(17)=2.09, p=0.05 ; 0.3$ $\mathrm{mg} / \mathrm{kg}, \mathrm{t}(18)=5.97, p<0.001)$ (Fig. 2) and animals ad- ministered lower doses $(0.01 \mathrm{mg} / \mathrm{kg})$ of risperidone $(0.3$ $\mathrm{mg} / \mathrm{kg}, \mathrm{t}(18)=5.25, p<0.001)$. Similarly, risperidone produced a separate overall effect on targeted forms of offensive attack (lateral attack; $\mathrm{F}_{(3,35)}=9.81, p<0.001$ ) and bite (flank/rear bites; $\mathrm{F}_{(3,35)}=17.06, p<0.001$ ) behavior within the same (and extended) anti-aggressive dose range. At these doses, risperidone treatment significantly decreased the number of lateral attacks $(0.3 \mathrm{mg} / \mathrm{kg}, \mathrm{t}(18)=$ $5.19, p<0.001)$ and flank $/$ rear bites $(0.01 \mathrm{mg} / \mathrm{kg}, \mathrm{t}(14)=$ $2.61, p<0.05 ; 0.1 \mathrm{mg} / \mathrm{kg}, \mathrm{t}(17)=4.94, p<0.001 ; 0.3$ $\mathrm{mg} / \mathrm{kg}, \mathrm{t}(18)=6.24, p<0.001)$ towards intruders when compared to saline $(0.0 \mathrm{mg} / \mathrm{kg}$ ) controls (Fig. 4). However, at lower doses of risperidone there were also significant decreases in the number of lateral attacks and flank/rear bites of aggressive animals towards intruders when compared with higher doses of risperidone (lateral attacks, 0.01 vs. 0.1 [t $(17)=6.10, p<0.001], 0.01$ vs. 0.3 [t $(18)=$ 5.17, $p<0.001$ ], 0.1 vs. 0.3 [t $(21)=3.38, p<0.01$ ]; flank/rear bites, 0.01 vs. 0.3 [t (18) $=3.2, p<0.01$ ], 0.1 vs. 0.3 [t $(21)=2.16, p<0.05])$. Risperidone also produced an overall effect on aggressive impulsivity as measured by latency to attack $\left(\mathrm{F}_{(3,35)}=5.18, p<0.01\right)$ and latency to bite $\left(\mathrm{F}_{(3,35)}=10.22, p<0.001\right)$ with the most effective anti-aggressive effect seen at the $0.3 \mathrm{mg} / \mathrm{kg}$ dose. At this dose, risperidone significantly reduced latency to attack intruders when compared with saline-treated control $(0.0 \mathrm{mg} / \mathrm{kg})$ animals $(\mathrm{t}(18)=2.99, p<0.01)$ and animals administered lower doses $(0.01 \mathrm{mg} / \mathrm{kg})$ of risperidone ( $\mathrm{t}(18)=2.64, p<0.05$ ) (Fig. 4). Risperidone also significantly reduced latency to bite intruders compared to saline-treated control $(0.0 \mathrm{mg} / \mathrm{kg})$ animals with the anti-aggressive effects first seen at a lower dose $(0.1 \mathrm{mg} / \mathrm{kg})$ 


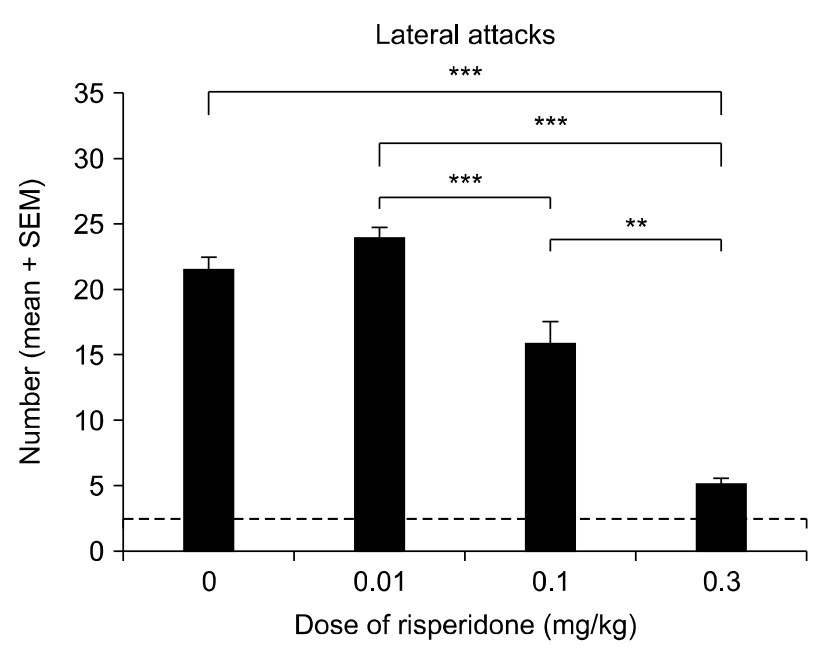

Latency to attacks

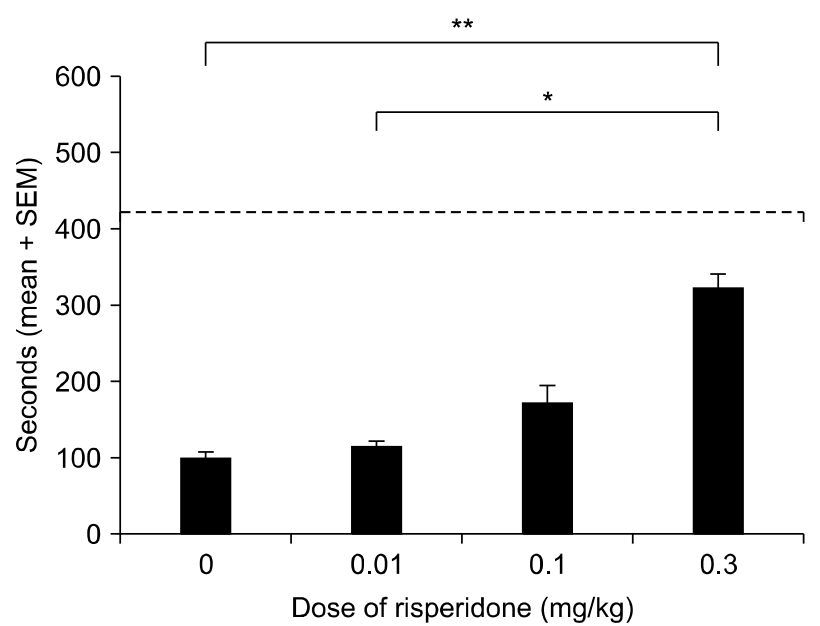

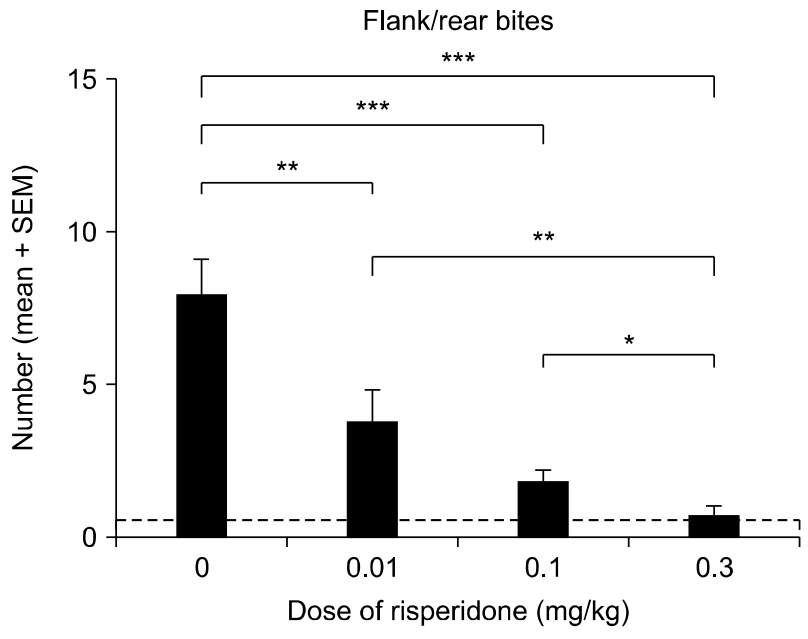

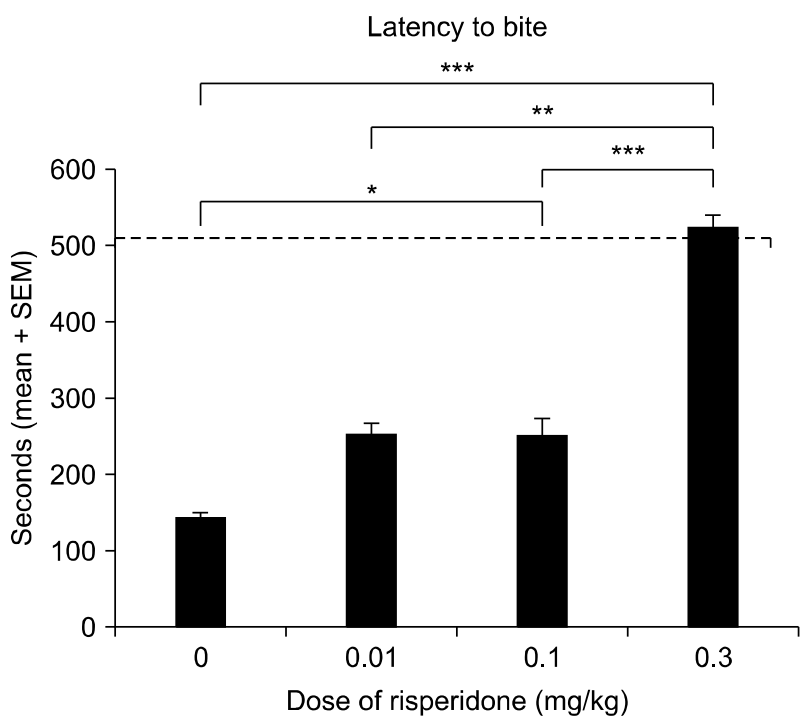

Fig. 4. Effects of risperidone on aggression. Risperidone treatment $(0.01-0.3 \mathrm{mg} / \mathrm{kg}$, intraperitoneal) produced a dose dependent reduction in each measure of aggression intensity (i.e., number of lateral attacks and flank/rump bites) and initiation (i.e., mean latency to first attack and bite). Dashed lines in represent the baseline behavioral response of non-aggressive, control animals. Bars denote standard error of the mean. ${ }^{*} p<0.05,{ }^{* *} p<0.01,{ }^{* * *} p<0.001$.

of risperidone $(\mathrm{t}(17)=2.64, p<0.05)$. At higher doses $(0.3 \mathrm{mg} / \mathrm{kg})$ risperidone had more significant anti-aggressive effects compared to saline-treated control $(0.0$ $\mathrm{mg} / \mathrm{kg}$ ) animals (t (18) $=5.36, p<0.001)$ and animals administered lower doses of risperidone $(0.01 \mathrm{mg} / \mathrm{kg}, \mathrm{t}(18)=$ $2.89, p<0.01 ; 0.1 \mathrm{mg} / \mathrm{kg}, \mathrm{t}(21)=3.36, p<0.01)$.

Unlike haloperidol, the systemic administration of risperidone at all doses failed to produce significant effects on ancillary measures of behavior, including flank marking $\left(\mathrm{F}_{(3,24)}=1.71\right)$ line crosses $\left(\mathrm{F}_{(3,24)}=0.89\right)$, grooming $\left(\mathrm{F}_{(3,24)}=0.70\right)$ or wall climbing $\left(\mathrm{F}_{(3,24)}=1.26\right)(p>0.05$ each comparison; Table 2).

\section{Anticonvulsants and Maladaptive Aggression}

\section{Valproate}

The systemic administration of valproate to aggressive, experimental animals produced an overall effect on aggression intensity as measured by composite scores of offensive aggression $\left(\mathrm{F}_{(3,35)}=10.76, p<0.001\right)$ with anti-aggressive effects beginning at the $1 \mathrm{mg} / \mathrm{kg}$ dose and continuing to the maximum dose $(10 \mathrm{mg} / \mathrm{kg})$ intruders when compared with saline-treated control $(0.0 \mathrm{mg} / \mathrm{kg})$ animals $(1 \mathrm{mg} / \mathrm{kg}$, t $(16)=2.64, p<0.05 ; 5 \mathrm{mg} / \mathrm{kg}$, t (16) = $5.25, p<0.001 ; 10 \mathrm{mg} / \mathrm{kg}$, t $(16)=3.85, p<0.01$ ) (Fig. 2 ) and animals administered lower doses ( $1 \mathrm{mg} / \mathrm{kg})$ of ris- 
Table 2. Effects of risperidone on ancillary behavior

\begin{tabular}{|c|c|c|c|c|c|}
\hline \multirow{2}{*}{ Behavior } & \multicolumn{5}{|c|}{ Dose } \\
\hline & $0.0 \mathrm{mg} / \mathrm{kg}$ & $0.01 \mathrm{mg} / \mathrm{kg}$ & $0.1 \mathrm{mg} / \mathrm{kg}$ & $0.3 \mathrm{mg} / \mathrm{kg}$ & $p$ value \\
\hline \multicolumn{6}{|l|}{ Social behavior } \\
\hline Flank marks & $2.25 \pm 0.58$ & $4.01 \pm 1.83$ & $1.82 \pm 0.37$ & $1.47 \pm 0.53$ & 0.26 \\
\hline \multicolumn{6}{|l|}{ Locomotion } \\
\hline Line crosses & $33.39 \pm 4.88$ & $38.36 \pm 4.86$ & $31.01 \pm 6.54$ & $34.42 \pm 4.77$ & 0.46 \\
\hline \multicolumn{6}{|c|}{ Comfort behavior } \\
\hline Grooming & $3.43 \pm 0.91$ & $2.86 \pm 0.62$ & $3.36 \pm 0.92$ & $2.92 \pm 0.82$ & 0.56 \\
\hline \multicolumn{6}{|c|}{ Avoidance/escape } \\
\hline Wall climbs & $18.25 \pm 4.58$ & $17.75 \pm 3.04$ & $15.33 \pm 1.15$ & $17.42 \pm 4.04$ & 0.31 \\
\hline
\end{tabular}

Values are presented as mean \pm standard deviation. Risperidone has no significant effects on any measure of ancillary behavior.

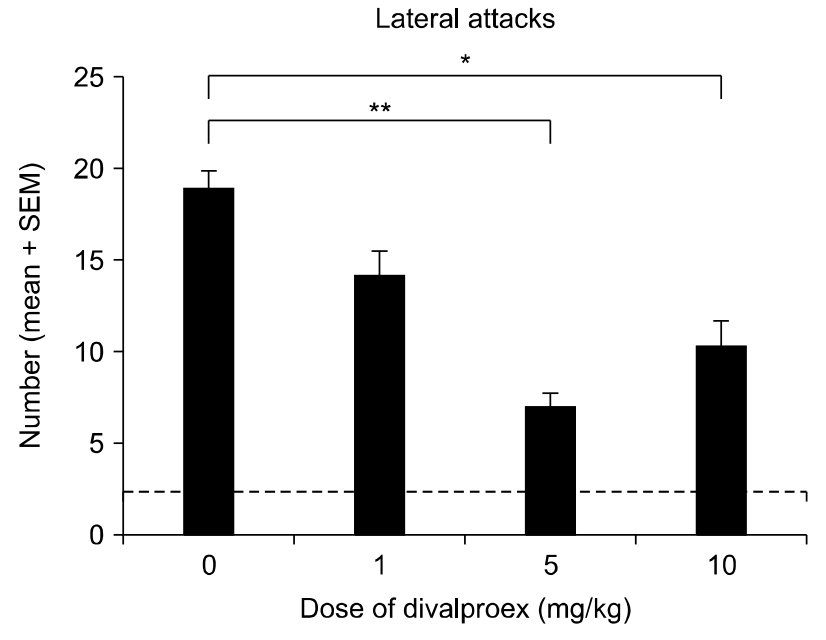

Latency to attacks

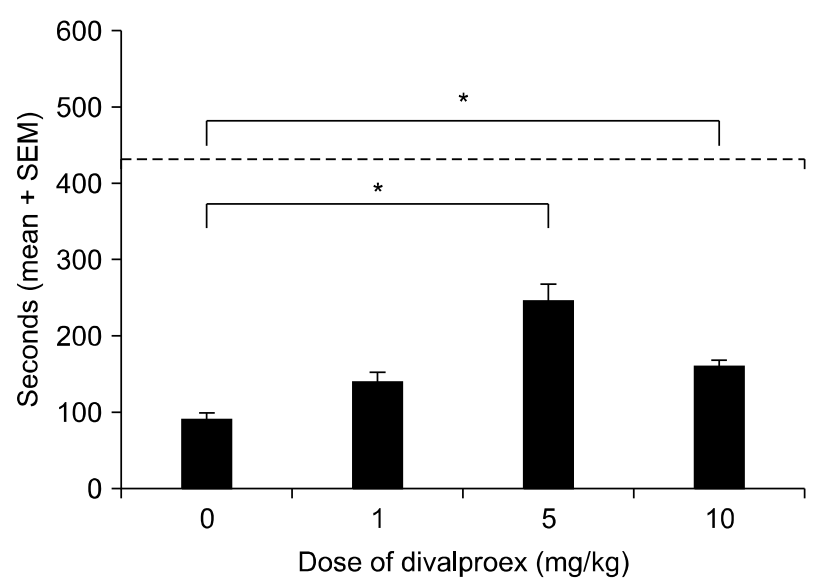

Flank/rear bites

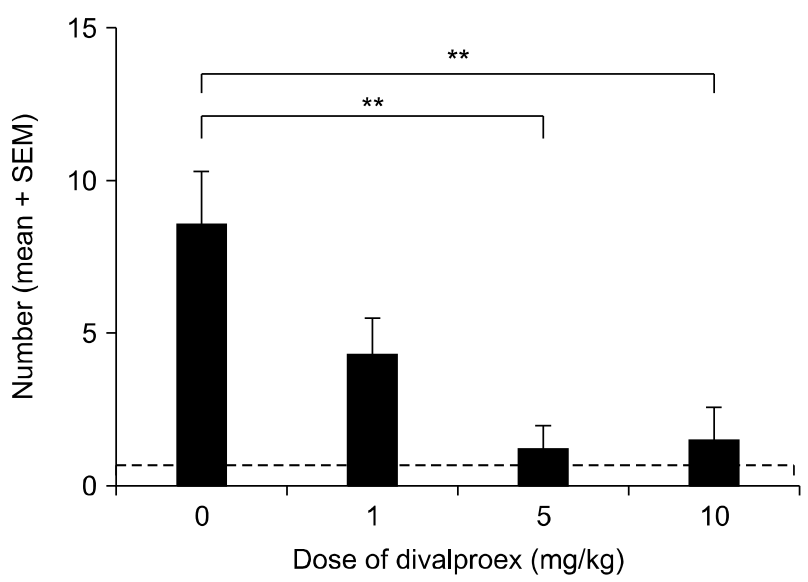

Latency to bite

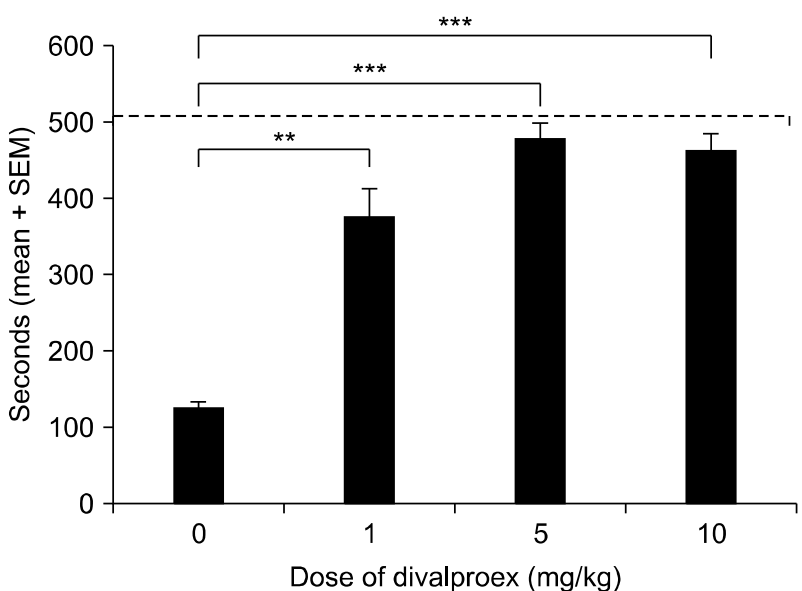

Fig. 5. Effects of valproate on aggression. Valproate treatment $(1-10 \mathrm{mg} / \mathrm{kg}$, intraperitoneal) produced a dose dependent reduction in each measure of aggression intensity (i.e., number of lateral attacks and flank/rump bites) and initiation (i.e., mean latency to first attack and bite). Dashed lines in represent the baseline behavioral response of non-aggressive, control animals. Bars denote standard error of the mean. ${ }^{*} p<0.05,{ }^{* *} p<0.01,{ }^{* * *} p<0.001$. 
Table 3. Effects of valproate on ancillary behavior

\begin{tabular}{|c|c|c|c|c|c|}
\hline \multirow{2}{*}{ Behavior } & \multicolumn{5}{|c|}{ Dose } \\
\hline & $0.0 \mathrm{mg} / \mathrm{kg}$ & $1 \mathrm{mg} / \mathrm{kg}$ & $5 \mathrm{mg} / \mathrm{kg}$ & 10 mg/kg & $p$ value \\
\hline \multicolumn{6}{|l|}{ Social behavior } \\
\hline Flank marks & $2.11 \pm 0.56$ & $3.01 \pm 1.38$ & $2.50 \pm 0.93$ & $2.25 \pm 1.23$ & 0.91 \\
\hline \multicolumn{6}{|l|}{ Locomotion } \\
\hline Line crosses & $30.6 \pm 2.82$ & $25.6 \pm 2.32$ & $26 \pm 2.60$ & $24.8 \pm 2.14$ & 0.26 \\
\hline \multicolumn{6}{|l|}{ Comfort behavior } \\
\hline Grooming & $3.12 \pm 0.74$ & $4.01 \pm 0.72$ & $5.04 \pm 0.46$ & $3.86 \pm 0.63$ & 0.25 \\
\hline \multicolumn{6}{|l|}{ Avoidance/escape } \\
\hline Wall climbs & $7.75 \pm 1.51$ & $8.25 \pm 2.82$ & $10.5 \pm 2.59$ & $6.62 \pm 2.14$ & 0.53 \\
\hline
\end{tabular}

Values are presented as mean \pm standard deviation. Valproate has no significant effects on any measure of ancillary behavior.

peridone $(5 \mathrm{mg} / \mathrm{kg}, \mathrm{t}(16)=3.17, p<0.01)$. Similarly, valproate produced a separate overall effect on targeted forms of offensive attack (lateral attack; $\mathrm{F}_{(3,34)}=3.26, p<$ 0.05 ) and bite (flank/rear bites; $\mathrm{F}_{(3,32)}=5.57, p<0.01$ ) behavior, but within a narrower anti-aggressive dose range. Valproate treatment significantly decreased the number of lateral attacks $(5 \mathrm{mg} / \mathrm{kg}, \mathrm{t}(16)=3.56, p<0.01 ; 10 \mathrm{mg} / \mathrm{kg}$, $\mathrm{t}(16)=2.21, p<0.05)$ and flank $/$ rear bites $(5 \mathrm{mg} / \mathrm{kg}, \mathrm{t}(16)=$ $3.37, p<0.01 ; 10 \mathrm{mg} / \mathrm{kg}, \mathrm{t}(16)=2.82, p=0.01$ ) towards intruders when compared to saline $(0.0 \mathrm{mg} / \mathrm{kg})$ controls (Fig. 5). Valproate also produced an overall effect on aggressive impulsivity as measured by latency to attack $\left(\mathrm{F}_{(3,34)}=3.17, p<0.05\right)$ and latency to bite $\left(\mathrm{F}_{(3,34)}=6.97\right.$, $p<0.001$ ) with the most effective anti-aggressive effects seen at the higher $(5 \mathrm{mg} / \mathrm{kg}$ and $10 \mathrm{mg} / \mathrm{kg}$ ) doses. Valproate significantly reduced latency to attack intruders when compared with saline-treated control $(0.0 \mathrm{mg} / \mathrm{kg})$ animals $(5 \mathrm{mg} / \mathrm{kg}, \mathrm{t}(16)=2.30, p<0.05 ; 10 \mathrm{mg} / \mathrm{kg}, \mathrm{t}(16)=$ 2.24, $p<0.05$ ) (Fig. 5). Valproate also significantly reduced latency to bite intruders compared to saline-treated control $(0.0 \mathrm{mg} / \mathrm{kg})$ animals across the wider dose range of valproate $(1 \mathrm{mg} / \mathrm{kg}, \mathrm{t}(16)=3.58, p<0.01 ; 5 \mathrm{mg} / \mathrm{kg}, \mathrm{t}(16)=$ $5.05, p<0.001 ; 10 \mathrm{mg} / \mathrm{kg}, \mathrm{t}(16)=4.86, p<0.001)$.

As observed with risperidone, the systemic administration of valproate at all doses failed to produce significant effects on ancillary measures of behavior, including flank marking $\left(\mathrm{F}_{(3,28)}=0.18\right)$, line crosses $\left(\mathrm{F}_{(3,28)}=\right.$ $1.42)$, grooming $\left(F_{(3,24)}=1.45\right)$, or wall climbing $\left(F_{(3,24)}=\right.$ 0.75) ( $p>0.05$ each comparison; Table 3$)$.

\section{DISCUSSION}

Maladaptive aggression is a form of aggressive behavior that does not serve a purpose and is a common symptom of mental health disorders [1]. Treatment of this type of aggression in youth with psychopharmacological interventions is becoming increasingly common [13], despite definitive evidence supporting the efficacy of off-label psychotropic medication use in adolescents for maladaptive aggression. In particular, the typical antipsychotic haloperidol, the atypical antipsychotic risperidone and the anticonvulsant mood stabilizer valproate have been shown to decrease aggressive behavior in youth $[16,20$, 28-32,60], and as a result, are being used to treat maladaptive aggressive behavior in adolescents [21]. To date there is little information available regarding whether these medications exhibit aggression-specific suppression in preclinical studies employing validated, adolescent animal models of maladaptive aggression. This information is critical to impart clinical confidence in the pharmacological ability of these agents to exert aggression-selective effects and to facilitate more data driven, child and adolescent prescription.

The current studies examined the effects of haloperidol, risperidone, and valproate on features of aggressive behavior that characterize maladaptive aggression using an established and validated adolescent animal model of maladaptive aggression. Specifically, experimental pubertal hamsters pre-treated with testosterone display a highly impulsive, intense, and targeted aggressive phenotype stereotypic of maladaptive aggression [46,61]. Results from the present studies show that at moderate doses (i.e., 0.025 and $0.05 \mathrm{mg} / \mathrm{kg}$ ), haloperidol reduced aggression intensity (i.e., number of flank/rear bites) and aggressive impulsivity (i.e., latency to bite). However, while haloperidol was marginally effective at reducing the impulsive 
and intense form of aggression in experimental animals, its effects appear to be non-specific as the decrease in aggression observed in experimental animals administered haloperidol was concurrent with reductions in both motor and grooming ancillary behaviors - suggesting that reductions in aggressive responding may be due to decreases in more general aspects of behavioral activation. In particular, the significant reduction in motor behavior observed in haloperidol-treated animals alone may explain why animals were slower to bite and successfully target fewer bites onto intruders than saline or low dose animals. Indeed, haloperidol is a monoaminergic antagonist with high affinity $(0.74 \mathrm{nM})$ for dopamine type 2 (DA2) receptors [62]. The blockade of DA D2 receptors using DA D2 antagonists or the genetic deletion of the long form of the DA D2 receptor has been shown to reduce aggressive behavior by significantly reducing motor behavior [63-66]. Risperidone and valproate also reduced the highly impulsive and intense form of aggression in experimental animals in a dose-dependent manner, with a significant reduction in aggression observed at 0.1 $\mathrm{mg} / \mathrm{kg}$ for risperidone and $5 \mathrm{mg} / \mathrm{kg}$ for valproate for most responses of aggression intensity and aggressive impulsivity. However, at these doses, the effects of risperidone and valproate were selective for aggression as the anti-aggressive effects were observed without concomitant effects on social communication (i.e., flank marking), motor behavior (i.e., locomotion), comfort behavior (i.e., grooming), or avoidance/escape behavior (i.e., wall climbing).

Behavioral data from these studies support the notion that risperidone and valproate serve as valid treatment strategies for maladaptive aggression in youth. For instance, experimental animals administered saline prior to aggression testing presented with a highly impulsive and intense display of aggression, analogous to that observed in our previous studies $[46,61]$. In contrast, administration of risperidone or valproate to aggressive, experimental animals prior to behavioral testing selectively reduced aggressive responding, with the most effective doses being $0.3 \mathrm{mg} / \mathrm{kg}$ and $5 \mathrm{mg} / \mathrm{kg}$, respectively. Risperidone and valproate -treated hamsters showed a $70-75 \%$ decrease in aggression intensity and $200-400 \%$ decrease in aggressive impulsivity at the $0.3 \mathrm{mg} / \mathrm{kg}$ and $5 \mathrm{mg} / \mathrm{kg}$ doses, respectively, when each is compared to their saline-treated counterparts. To determine whether the effects of risperidone and valproate were selective for specific and tar- geted measures of the aggressive response, the anti-aggressive properties of these drugs were analyzed across several determinates of aggression. Specifically, consistent with the decrease in composite aggression scores, at the effective dose of risperidone $(0.3 \mathrm{mg} / \mathrm{kg})$ and valproate $(5 \mathrm{mg} / \mathrm{kg})$, animals showed a $65-75 \%$ decrease in the number of lateral attacks and $85-90 \%$ decrease in number of flank/rear bites compared to saline-treated controls. These findings are particularly interesting given that bites targeted towards the flank/rear region of the intruder are highly organized, mature aspects of the aggressive phenotype [62-64,67-69]. The highly selective nature of risperidone and valproate's anti-aggressive effects combined with the lack of any measurable effect on social communication, locomotion, comfort or avoidance/escape behavior, indicated that these drugs did not attenuate aggressive responding through general nonspecific behavioral inhibition or sedation. These data suggest that risperidone and valproate may be effective at attenuating a highly impulsive and intense form of aggression in adolescents, and as a result, these findings support an indication for the use of these medications for early-onset maladaptive aggression in referred youth.

Risperidone and valproate may attenuate maladaptive aggression by their actions on select brain systems and neurochemical signals implicated in the control of aggressive behavior. Risperidone is a monoaminergic antagonist with high affinity $(0.71 \mathrm{nM})$ for serotonin type $2 \mathrm{~A}$ (5HT2A) receptors $[62,70]$, while valproate increases the activity of the inhibitory neurotransmitter $\gamma$ aminobutyric acid (GABA) likely through GABA type $A$ receptors (i.e., the majority of GABA receptors in brain $[71,72]$. The serotonin 5HT and GABA neural systems have been implicated in the regulation of aggressive behavior [73-80], and the importance of 5HT2A and GABA A receptors as mediators of the aggressive response has been demonstrated. For instance, the activation of $5 \mathrm{HT} 2 \mathrm{~A}$ receptors with agonists increase aggressive behavior [81], while $5 \mathrm{HT} 2 \mathrm{~A}$ receptor blockade with antagonists (and mixed 5HT2A/DA D2 receptor antagonists) decreases aggression [40,81-83] in rodents, including hamsters [42,43], suggesting an stimulatory role of $5 \mathrm{HT} 2 \mathrm{~A}$ receptor signaling in aggressive behavior. Conversely, the blockade of GABA A receptors using antagonists significantly also increases aggression [84,85], suggesting an inhibitory role of GABA A receptor signaling in aggression control. Interestingly, in 
the adolescent animal model of maladaptive aggression used in this study, highly aggressive, experimental animals possessed significant increases in 5HT2A receptors [86] alongside concomitant decreases in GABA A receptors [87] within key brain regions integral in modulating aggressive behavior, most notably the latero-anterior hypothalamus $(\mathrm{LAH})$. These findings indicate that aggressive, experimental animals have heightened $5 \mathrm{HT} 2 \mathrm{~A}$ receptor signaling and reduced GABA A receptor signaling in brain regions controlling aggression. It is plausible that $5 \mathrm{HT} 2 \mathrm{~A}$ receptor antagonism by risperidone and GABA A receptor agonism by valproate act within the $\mathrm{LAH}$ to mitigate the highly reactive, maladaptive aggressive phenotype observed in experimental animals. Taken together, the ability of these agents to modulate highly escalated aggressive behavior emphasizes the role of $5 \mathrm{HT}$ and GABA acting through $5 \mathrm{HT} 2 \mathrm{~A}$ and GABA A receptors as important molecular components of the neural circuit that serves to modulate maladaptive aggression.

Given the documented rise in the pharmacological treatment of maladaptive aggression in youth populations [13], it is vital to dedicate research to exploring the relative efficacies of various pharmacological interventions. In this study, we used a well-validated pharmacologic adolescent animal model of maladaptive aggression to demonstrate the highly selective anti-aggressive properties of the atypical antipsychotic risperidone and the anticonvulsant mood stabilizer valproate. The pre-clinical behavioral data presented here are important and novel in that they indicate that risperidone and valproate may possess selective and targeted anti-aggressive effects; contributing to evidence that these drugs may used clinically as effective pharmacotherapeutics for selectively mitigating the highly reactive, maladaptive aggressive phenotype in adolescents [25,31,88-90]. These data not withstanding, further study of other atypical antipsychotics and anticonvulsant mood stabilizers in the treatment of maladaptive aggression across well-validated aggression subtypes and in psychiatric diagnoses with a high prevalence of reactive, maladaptive aggression is warranted in both pre-clinical and clinical studies.

\section{Acknowledgments}

This research was supported by research grant number R01 DA10547 from the National Institute on Drug Abuse (NIDA) to R.M.. Its contents are solely the responsibility of the authors and do not necessarily represent the official views of NIDA. The authors have no conflicts of interest to declare.

\section{- Conflicts of Interest}

No potential conflict of interest relevant to this article was reported.

\section{Author Contributions}

Conceptualization: Richard Melloni, Jr. Data acquisition: Amanda Puckett, Lesley Ricci. Formal analysis: Clare Einberger, Richard Melloni, Jr. Writing-original draft: Clare Einberger, Richard Melloni, Jr. Writing-review\&editing: Richard Melloni, Jr. Supervision: Lesley Ricci, Richard Melloni, Jr. Funding: Richard Melloni, Jr.

\section{ORCID}

Clare Einberger

Amanda Puckett

https://orcid.org/0000-0001-5059-5899

Lesley Ricci

https://orcid.org/0000-0003-0442-6255

https://orcid.org/0000-0003-4285-6002

Richard Melloni Jr. https://orcid.org/0000-0002-2203-3685

\section{REFERENCES}

1. Connor DF. Aggression and antisocial behavior in children and adolescents: research and treatment. New York:Guilford Press;2002.

2. Kessler RC, Coccaro EF, Fava M, Jaeger S, Jin R, Walters E. The prevalence and correlates of DSM-IV intermittent explosive disorder in the National Comorbidity Survey replication. Arch Gen Psychiatry 2006;63:669-678.

3. Vitaro F, Gendreau PL, Tremblay RE, Oligny P. Reactive and proactive aggression differentially predict later conduct problems. J Child Psychol Psychiatry 1998;39:377-385.

4. Haller J, Kruk MR. Normal and abnormal aggression: human disorders and novel laboratory models. Neurosci Biobehav Rev 2006;30:292-303.

5. Kanne SM, Mazurek MO. Aggression in children and adolescents with ASD: prevalence and risk factors. J Autism Dev Disord 2011;41:926-937.

6. Dyer KF, Dorahy MJ, Hamilton G, Corry M, Shannon M, MacSherry A, et al. Anger, aggression, and self-harm in PTSD and complex PTSD. J Clin Psychol 2009;65:1099-1114.

7. Harris AW, Large MM, Redoblado-Hodge A, Nielssen O, Anderson J, Brennan J. Clinical and cognitive associations with aggression in the first episode of psychosis. Aust N Z J Psychiatry 2010;44:85-93.

8. Doerfler LA, Connor DF, Toscano PF Jr. Aggression, $A D H D$ symptoms, and dysphoria in children and adolescents diagnosed with bipolar disorder and ADHD. I Affect Disord 
2011;131:312-319.

9. Ballester J, Goldstein T, Goldstein B, Obreja M, Axelson D, Monk K, et al. Is bipolar disorder specifically associated with aggression? Bipolar Disord 2012;14:283-290.

10. Pingault JB, Côté SM, Lacourse E, Galéra C, Vitaro F, Tremblay RE. Childhood hyperactivity, physical aggression and criminality: a 19-year prospective population-based study. PLoS One 2013;8:e62594.

11. Connor DF, Ozbayrak KR, Harrison RJ, Melloni RH Jr. Prevalence and patterns of psychotropic and anticonvulsant medication use in children and adolescents referred to residential treatment. J Child Adolesc Psychopharmacol 1998;8: 27-38.

12. Connor DF, Ozbayrak KR, Kusiak KA, Caponi AB, Melloni RH Jr. Combined pharmacotherapy in children and adolescents in a residential treatment center. I Am Acad Child Adolesc Psychiatry 1997;36:248-254.

13. Knapp P, Chait A, Pappadopulos E, Crystal S, Jensen PS. Treatment of maladaptive aggression in youth: CERT guidelines I. Engagement, assessment, and management. Pediatrics 2012;129:e1562-e1576.

14. Schur SB, Sikich L, Findling RL, Malone RP, Crismon ML, Derivan A, et al. Treatment recommendations for the use of antipsychotics for aggressive youth (TRAAY). Part I: a review. J Am Acad Child Adolesc Psychiatry 2003;42:132-144.

15. Findling RL, Steiner H, Weller EB. Use of antipsychotics in children and adolescents. J Clin Psychiatry 2005;66 Supp/ 7:29-40.

16. Saxena K, Howe M, Simeonova D, Steiner H, Chang K. Divalproex sodium reduces overall aggression in youth at high risk for bipolar disorder. J Child Adolesc Psychopharmacol 2006; 16:252-259.

17. Alexander GC, Gallagher SA, Mascola A, Moloney RM, Stafford RS. Increasing off-label use of antipsychotic medications in the United States, 1995-2008. Pharmacoepidemiol Drug Saf 2011;20:177-184.

18. Comer JS, Olfson M, Mojtabai R. National trends in child and adolescent psychotropic polypharmacy in office-based practice, 1996-2007. J Am Acad Child Adolesc Psychiatry 2010; 49:1001-1010.

19. Olfson M, Blanco C, Liu L, Moreno C, Laje G. National trends in the outpatient treatment of children and adolescents with antipsychotic drugs. Arch Gen Psychiatry 2006;63:679-685.

20. Campbell M, Small AM, Green WH, Jennings SJ, Perry R, Bennett WG, et al. Behavioral efficacy of haloperidol and lithium carbonate. A comparison in hospitalized aggressive children with conduct disorder. Arch Gen Psychiatry 1984;41: 650-656.

21. Pringsheim T, Hirsch L, Gardner D, Gorman DA. The pharmacological management of oppositional behaviour, conduct problems, and aggression in children and adolescents with attention-deficit hyperactivity disorder, oppositional defiant disorder, and conduct disorder: a systematic review and meta-analysis. Part 1: psychostimulants, alpha-2 agonists, and atomoxetine. Can J Psychiatry 2015;60:42-51.

22. Gorman DA, Gardner DM, Murphy AL, Feldman M, Bélanger SA, Steele MM, et al. Canadian guidelines on pharmacotherapy for disruptive and aggressive behaviour in children and adolescents with attention-deficit hyperactivity disorder, oppositional defiant disorder, or conduct disorder. Can J Psychiatry 2015;60:62-76.

23. van Schalkwyk Gl, Beyer C, Johnson J, Deal M, Bloch MH. Antipsychotics for aggression in adults: a meta-analysis. Prog Neuropsychopharmacol Biol Psychiatry 2018;81:452-458.

24. Arana GW. An overview of side effects caused by typical antipsychotics. J Clin Psychiatry 2000;61 Suppl 8:5-11.

25. Harrison-Woolrych M, Garcia-Quiroga J, Ashton J, Herbison P. Safety and usage of atypical antipsychotic medicines in children: a nationwide prospective cohort study. Drug Saf 2007;30:569-579.

26. Aman MG, De Smedt G, Derivan A, Lyons B, Findling RL. Double-blind, placebo-controlled study of risperidone for the treatment of disruptive behaviors in children with subaverage intelligence. Am J Psychiatry 2002;159:1337-1346.

27. Van Bellinghen M, De Troch C. Risperidone in the treatment of behavioral disturbances in children and adolescents with borderline intellectual functioning: a double-blind, placebo-controlled pilot trial. J Child Adolesc Psychopharmacol 2001;11:5-13.

28. Findling RL, McNamara NK, Branicky LA, Schluchter MD, Lemon E, Blumer JL. A double-blind pilot study of risperidone in the treatment of conduct disorder. J Am Acad Child Adolesc Psychiatry 2000;39:509-516.

29. McCracken JT, McGough J, Shah B, Cronin P, Hong D, Aman MG, et al.; Research Units on Pediatric Psychopharmacology Autism Network. Risperidone in children with autism and serious behavioral problems. N Engl J Med 2002;347:314-321.

30. Kavoussi RJ, Coccaro EF. Divalproex sodium for impulsive aggressive behavior in patients with personality disorder. J Clin Psychiatry 1998;59:676-680.

31. Barzman DH, DelBello MP, Adler CM, Stanford KE, Strakowski $\mathrm{SM}$. The efficacy and tolerability of quetiapine versus divalproex for the treatment of impulsivity and reactive aggression in adolescents with co-occurring bipolar disorder and disruptive behavior disorder(s). J Child Adolesc Psychopharmacol 2006; 16:665-670.

32. Steiner H, Petersen ML, Saxena K, Ford S, Matthews Z. Divalproex sodium for the treatment of conduct disorder: a randomized controlled clinical trial. J Clin Psychiatry 2003; 64:1183-1191.

33. Vitiello B, Stoff DM. Subtypes of aggression and their relevance to child psychiatry. J Am Acad Child Adolesc Psychiatry 1997;36:307-315.

34. Bambauer KZ, Connor DF. Characteristics of aggression in clinically referred children. CNS Spectr 2005;10:709-718.

35. Blanchard DC, Blanchard RJ. What can animal aggression re- 
search tell us about human aggression? Horm Behav 2003; 44:171-177.

36. Moyer KE. A model of aggression with implications for research [proceedings]. Psychopharmacol Bull 1977;13:14-15.

37. Eichelman B. Aggressive behavior: from laboratory to clinic. Quo vadit? Arch Gen Psychiatry 1992;49:488-492.

38. Blair RJ. The roles of orbital frontal cortex in the modulation of antisocial behavior. Brain Cogn 2004;55:198-208.

39. Rodríguez-Arias M, Miñarro J, Aguilar MA, Pinazo J, Simón VM. Effects of risperidone and SCH 23390 on isolation-induced aggression in male mice. Eur Neuropsychopharmacol 1998; 8:95-103.

40. Skrebuhhova-Malmros T, Pruus K, Rudissaar R, Allikmets L, Matto $\mathrm{V}$. The serotonin 5-HT(2A) receptor subtype does not mediate apomorphine-induced aggressive behaviour in male Wistar rats. Pharmacol Biochem Behav 2000;67:339-343.

41. Moechars D, Gilis M, Kuipéri C, Laenen I, Van Leuven F. Aggressive behaviour in transgenic mice expressing APP is alleviated by serotonergic drugs. Neuroreport 1998;9:35613564.

42. Ricci LA, Connor DF, Morrison R, Melloni RH Jr. Risperidone exerts potent anti-aggressive effects in a developmentally immature animal model of escalated aggression. Biol Psychiatry 2007;62:218-225.

43. Schwartzer JJ, Morrison RL, Ricci LA, Melloni RH Jr. Paliperidone suppresses the development of the aggressive phenotype in a developmentally sensitive animal model of escalated aggression. Psychopharmacology (Berl) 2009;203: 653-663.

44. Grimes JM, Ricci LA, Melloni RH Jr. Plasticity in anterior hypothalamic vasopressin correlates with aggression during anabolic-androgenic steroid withdrawal in hamsters. Behav Neurosci 2006;120:115-124.

45. Harrison RJ, Connor DF, Nowak C, Nash K, Melloni RH Jr. Chronic anabolic-androgenic steroid treatment during adolescence increases anterior hypothalamic vasopressin and aggression in intact hamsters. Psychoneuroendocrinology 2000;25:317-338.

46. Melloni RH Jr, Ricci LA. Adolescent exposure to anabolic/androgenic steroids and the neurobiology of offensive aggression: a hypothalamic neural model based on findings in pubertal Syrian hamsters. Horm Behav 2010;58:177-191.

47. Morrison TR, Sikes RW, Melloni RH Jr. Anabolic steroids alter the physiological activity of aggression circuits in the lateral anterior hypothalamus. Neuroscience 2016;315:1-17.

48. Miczek KA, Fish EW, De Bold JF. Neurosteroids, GABAA receptors, and escalated aggressive behavior. Horm Behav 2003:44:242-257.

49. Ferris CF, Melloni RH Jr, Koppel G, Perry KW, Fuller RW, Delville $\mathrm{Y}$. Vasopressin/serotonin interactions in the anterior hypothalamus control aggressive behavior in golden hamsters. J Neurosci 1997;17:4331-4340.

50. Teixeira EH, Jacintho A, Celeri HV, Dalgalarrondo P. Atypical antipsychotics in the treatment of pathological aggression in children and adolescents: literature review and clinical recommendations. Trends Psychiatry Psychother 2013;35: 151-159.

51. Miller LL, Whitsett JM, Vandenbergh JG, Colby DR. Physical and behavioral aspects of sexual maturation in male golden hamsters. J Comp Physiol Psychol 1977;91:245-259.

52. Whitsett JM. The development of aggressive and marking behavior in intact and castrated male hamsters. Horm Behav 1975;6:47-57.

53. Ricci LA, Grimes JM, Melloni RH Jr. Serotonin type 3 receptors modulate the aggression-stimulating effects of adolescent cocaine exposure in Syrian hamsters (Mesocricetus auratus). Behav Neurosci 2004;118:1097-1110.

54. Ricci LA, Knyshevski I, Melloni RH Jr. Serotonin type 3 receptors stimulate offensive aggression in Syrian hamsters. Behav Brain Res 2005;156:19-29.

55. West GB, Brown JH. The origin of allometric scaling laws in biology from genomes to ecosystems: towards a quantitative unifying theory of biological structure and organization. J Exp Biol 2005;208:1575-1592.

56. Sharma $\mathrm{V}, \mathrm{McNeill} \mathrm{JH}$. To scale or not to scale: the principles of dose extrapolation. Br J Pharmacol 2009;157:907-921.

57. Floody OR, Pfaff DW. Aggressive behavior in female hamsters: the hormonal basis for fluctuations in female aggressiveness correlated with estrous state. J Comp Physiol Psychol 1977;91:443-464.

58. Lerwill CJ, Makings P. The agonistic behaviour of the golden hamster Mesocricetus auratus (waterhouse). Animal Behav 1971;19:714-721.

59. Grimes JM, Ricci LA, Melloni RH Jr. Glutamic acid decarboxylase (GAD65) immunoreactivity in brains of aggressive, adolescent anabolic steroid-treated hamsters. Horm Behav 2003;44:271-280.

60. Reyes M, Olah R, Csaba K, Augustyns I, Eerdekens M. Long-term safety and efficacy of risperidone in children with disruptive behaviour disorders. Results of a 2-year extension study. Eur Child Adolesc Psychiatry 2006;15:97-104.

61. Melloni RH Jr, Morrison TR, Ricci LA. The neuropathology of adolescent anabolic/androgenic steroid abuse: altered development of the reciprocal hypothalamic neural circuit controlling aggressive behavior. In: Preedy VR, editor. Neuropathology of drug addictions and substance misuse. Amsterdam:Academic Press;2016. p.945-957.

62. Schotte A, Janssen PF, Megens AA, Leysen JE. Occupancy of central neurotransmitter receptors by risperidone, clozapine and haloperidol, measured ex vivo by quantitative autoradiography. Brain Res 1993;631:191-202.

63. Arregui A, Azpiroz A, Brain PF, Simon V. Effects of two selective dopaminergic antagonists on ethologically-assessed encounters in male mice. Gen Pharmacol 1993;24:353-356.

64. Navarro JF, Manzaneque JM. Acute and subchronic effects of tiapride on isolation-induced aggression in male mice. 
Pharmacol Biochem Behav 1997;58:255-259.

65. Nikulina EM, Kapralova NS. Role of dopamine receptors in the regulation of aggression in mice; relationship to genotype. Neurosci Behav Physiol 1992;22:364-369.

66. Vukhac KL, Sankoorikal EB, Wang Y. Dopamine D2L receptor- and age-related reduction in offensive aggression. Neuroreport 2001;12:1035-1038.

67. Wommack JC, Taravosh-Lahn K, David JT, Delville Y. Repeated exposure to social stress alters the development of agonistic behavior in male golden hamsters. Horm Behav 2003;43:229-236.

68. Wommack JC, Delville Y. Repeated social stress and the development of agonistic behavior: individual differences in coping responses in male golden hamsters. Physiol Behav 2003:80:303-308.

69. Delville Y, David JT, Taravosh-Lahn K, Wommack JC. Stress and the development of agonistic behavior in golden hamsters. Horm Behav 2003;44:263-270.

70. Leysen JE, Janssen PM, Megens AA, Schotte A. Risperidone: a novel antipsychotic with balanced serotonin-dopamine antagonism, receptor occupancy profile, and pharmacologic activity. J Clin Psychiatry 1994;55 Suppl:5-12.

71. McKernan RM, Whiting PJ. Which GABAA-receptor subtypes really occur in the brain? Trends Neurosci 1996;19:139-143.

72. Löscher W. Valproate: a reappraisal of its pharmacodynamic properties and mechanisms of action. Prog Neurobiol 1999; 58:31-59.

73. Brown GL, Ebert MH, Goyer PF, Jimerson DC, Klein WJ, Bunney WE, et al. Aggression, suicide, and serotonin: relationships to CSF amine metabolites. Am I Psychiatry 1982; 139:741-746.

74. Brown GL, Goodwin FK, Ballenger JC, Goyer PF, Major LF. Aggression in humans correlates with cerebrospinal fluid amine metabolites. Psychiatry Res 1979;1:131-139.

75. Higley JD, Mehlman PT, Taub DM, Higley SB, Suomi SJ, Vickers JH, et al. Cerebrospinal fluid monoamine and adrenal correlates of aggression in free-ranging rhesus monkeys. Arch Gen Psychiatry 1992;49:436-441.

76. Kyes RC, Botchin MB, Kaplan JR, Manuck SB, Mann JJ. Aggression and brain serotonergic responsivity: response to slides in male macaques. Physiol Behav 1995;57:205-208.

77. Mehlman PT, Higley JD, Faucher I, Lilly AA, Taub DM, Vickers I, et al. Low CSF 5-HIAA concentrations and severe aggression and impaired impulse control in nonhuman primates. Am J Psychiatry 1994;151:1485-1491.

78. Miczek KA, Altman, J, Appel, JB, Boggan, WO. Para-chlorophenylalanine, serotonin, and killing behavior. Pharmacol Biochem Behav 1975;3:355-361.

79. Miczek KA, Mos J, Olivier B. Brain 5-HT and inhibition of aggressive behavior in animals: 5-HIAA and receptor subtypes. Psychopharmacol Bull 1989;25:399-403.

80. Vergnes M, Depaulis A, Boehrer A, Kempf E. Selective increase of offensive behavior in the rat following intrahypothalamic 5,7-DHT-induced serotonin depletion. Behav Brain Res 1988;29:85-91.

81. Sakaue M, Ago Y, Sowa C, Sakamoto Y, Nishihara B, Koyama $\mathrm{Y}$, et al. Modulation by 5- $h$ T2A receptors of aggressive behavior in isolated mice. Jpn J Pharmacol 2002;89:89-92.

82. Sánchez C, Arnt J, Hyttel J, Moltzen EK. The role of serotonergic mechanisms in inhibition of isolation-induced aggression in male mice. Psychopharmacology (Berl) 1993;110:53-59.

83. Shih JC, Ridd MJ, Chen K, Meehan WP, Kung MP, Seif I, et al. Ketanserin and tetrabenazine abolish aggression in mice lacking monoamine oxidase A. Brain Res 1999;835:104-112.

84. Rodgers RJ, Depaulis A. GABAergic influences on defensive fighting in rats. Pharmacol Biochem Behav 1982;17:451-456.

85. Shaikh MB, Siegel A. GABA-mediated regulation of feline aggression elicited from midbrain periaqueductal gray. Brain Res 1990;507:51-56.

86. Schwartzer JJ, Ricci LA, Melloni RH Jr. Adolescent anabolic-androgenic steroid exposure alters lateral anterior hypothalamic serotonin-2A receptors in aggressive male hamsters. Behav Brain Res 2009;199:257-262.

87. Schwartzer JJ, Ricci LA, Melloni RH Jr. Interactions between the dopaminergic and GABAergic neural systems in the lateral anterior hypothalamus of aggressive AAS-treated hamsters. Behav Brain Res 2009;203:15-22.

88. Coccaro EF, Kavoussi RJ. Fluoxetine and impulsive aggressive behavior in personality-disordered subjects. Arch Gen Psychiatry 1997; 54:1081-1088.

89. Khanzode LA, Saxena K, Kraemer H, Chang K, Steiner H. Efficacy profiles of psychopharmacology: divalproex sodium in conduct disorder. Child Psychiatry Hum Dev 2006;37:55-64.

90. Steiner H, Saxena K, Chang K. Psychopharmacologic strategies for the treatment of aggression in juveniles. CNS Spectr 2003;8:298-308. 